DOI: $10.20472 / B M .2019 .7 .2 .008$

\title{
DEVELOPMENT OF DEMAND-RELATED INFLATION PRESSURES ORIGINATING FROM THE HOUSEHOLD SECTOR IN THE CZECH REPUBLIC
}

\author{
EMILIE JASOVA
}

\begin{abstract}
:
The aim of the paper is to outline the development and the level of the demand-related inflation potential originating in the household sector in the Czech Republic. In order to achieve that, we will outline inflation types and their causes as reported by selected authors. We will also describe several ways of assessing and quantifying the demand-related inflation potential originating in the household sector, as published by the Czech National Bank. Furthermore, we will calculate the indicators of total potential demand-related inflation impulses from the household sector, whose development is to be compared with the household consumption deflator. The values of the overall relative income status of households will then be explained using their parallels for individual household income items. The quantification of the overall demand-related inflation potential from the household sector will then be carried out in the form of accumulating their values in terms of the localised periods of recession and boom in the GDP development in fixed prices.
\end{abstract}

\section{Keywords:}

Demand-related inflation potential from the household sector; overall relative household income status; relative household income status for individual household income components; overall real relative household income status

JEL Classification: E24, E32, E37

\section{Authors:}

EMILIE JASOVA, University of Economics in Prague, Czech Republic, Email: ekonomka_2@hotmail.com

\section{Citation:}

EMILIE JASOVA (2019). Development of demand-related inflation pressures originating from the household sector in the Czech Republic. International Journal of Business and Management, Vol. VII(2), pp. 110-126., 10.20472/BM.2019.7.2.008 


\section{Introduction}

Pospišil (2010) distinguishes three groups of inflation according to the related causes. These include the demand-related inflation (demand-driven inflation), caused by an excessive growth of private or public expenditure on goods and services and an excessive credit expansion of commercial banks. In addition, the author also mentions the cost-related inflation (cost-driven inflation), being the consequence of a fast growth of costs in the low productivity environment (e.g. excessive growth of wages or grow due to the producer's monopoly).

The Czech National Bank (January 2001b) assesses the impact of the wage development on inflation through the perspective of the double impact of wages on inflation development. According to its Methodological Framework of the Wage Development in Relation to Inflation, wages become a potential source of cost and wage related inflation pressures. And yet, it is difficult to distinguish these two types of price pressures. In the case of demand-related inflation (see the box), there is the effect of high demand on the retail prices development through the price policy of consumer goods sellers. According to the Czech National Bank, commercial sellers of consumer goods are in a close contact with customers and competitors, and as result, they may wish, given the high demand (at the boom period) and weak competition, to maximise their incomes and profits through increasing prices without the presence of cost pressures. At the time when the economy's output is below its potential, retail market competition prevents increasing sellers' prices without the existence of substantial cost pressures. Competition forces sellers to a moderate approach to their prices and to maximise their profit using non-price measures.

According to Janků (2008), demand-related inflation is encouraged by positive demand shocks in the case that the real potential product does not increase at a corresponding rate or the input prices do not decline accordingly. The growth in aggregate demand with the constant volume of aggregate supply will result in the growth of prices of the aggregate supply. Employees will require a pay rise, which will increase companies' costs and will lead to a new supply-side price increase. This inflation type is caused by national budget expenditures exceeding income, demand of companies for construction work and technologies exceeding their supply, a higher pressure of trade unions to wage growth than the relevant work productivity, a tax reduction leading to an increase in the volume of effective demand, and increase in the price of imported goods inspiring competing domestic companies to increase their prices. According to the author, cost-driven inflation is caused mainly by the negative supply shock which is not accompanied with a decline in the aggregate demand. The difference in initiating the process of the inflation spiral compared to demand-driven inflation consists in the first impulse for growing prices which is on the side of companies' aggregate supply. The main reasons for the occurrence of supply-related inflation include a vigorous growth in production costs (e.g. oil prices), obstacles to free fluctuation of prices imposed by the monopoly, natural and other disasters and administrative import barriers, and expectations of price increase among manufacturers leading to increasing their prices.

Similarly, Cempírek (2013) speaks of two inflation types. The difference between them consists in the impulse causing them. The reason for the occurrence of a demand-related inflation impulse includes the growth in a component of aggregate expenses, accompanied with the increase in the cash stock at the central bank. According to the author, demandrelated inflation is due to an increase in household consumption expenses, corporate investments, government expenses, net export, and money supply. Supply-related inflation occurs upon reducing aggregate supply due to supply shocks. Supply-related inflation shocks include various natural disasters (in the long term, they affect the production function of companies, reduce production resources, and increase prices) and the invariability of the 
economy's natural output, which is accompanied with growing corporate expenses, salaries and monopoly prices.

Šmídová (2004/2005) considers inflation as a sign of imbalance in the market, and according to the causes and in line with the two previous authors, she distinguishes demand-driven inflation which is caused by positive demand shocks without adequate increase in potential output or input prices decline. The demand-related inflation is caused, for instance, by a higher nominal wage growth than productivity, excessive investment spending, promoting cheap lending by the state, tax cuts and increased government spending. Cost-driven inflation is caused by negative supply shocks not accompanied by adequate decline in aggregate demand. Supply-related inflation is due to imperfect competition, increasing the total cost through the growth of wages as promoted by trade unions, political events, increasing raw material prices, and increased costs due to the transition to a lower-quality sources of raw materials or energy.

The work of Pavelka (2005) shows that when the economy is on or above the level of the potential product, it leads to demand-driven inflation. The source of demand-related may include increasing government spending not covered, for instance, by issuing government bonds, tax cuts increasing aggregate demand, low interest rated leading to an increase in investment spending, and income growth unsupported by the growth in work productivity. Cost-driven inflation is due to negative shocks on the supply-side of the market, when the real product is below the level of the potential product. This inflation type occurs as a result of growing production costs due to increasing the price of raw materials, which will increase prices, while this will lead to increasing wages and further growth in production costs.

Žák (2006) says that in the case of demand-related inflation, economic entities consume a larger product than produced by the economy, which leads to growing prices. The growth in the aggregate demand is due to an expansive government policy (the efforts to permanently maintain employment above the natural unemployment rate through increasing government spending) and an expansive monetary policy of the central bank (a faster growth rate of the money supply than the potential product). Supply-related inflation is caused by growing corporate expenses owing to a growth in nominal wage rates exceeding the growth in work productivity, increasing prices of raw materials and energies, and a growth in imported inflation as a consequence of a high devaluation or increasing prices of raw materials in world markets. In addition, the author also speaks of the inflation growth caused by inflation expectations. In this case, economic entities forecast the development of the inflation rate on the basis of the previous inflation rate and accordingly adapt their decision-making on prices, wages and interest rates. Inflation thus remains in the economy even without the presence of real inflation pressures in the form of demand and supply shocks.

According to Bowen (1960), it is not sufficient to talk about inflation in general but it is necessary to specify whether it is cost-related inflation, demand-related inflation, excessive demand-related inflation, wage inflation, monetary inflation, structural inflation, purchase inflation, sales inflation, administrative and price inflation, etc. The need to distinguish cost and demand-related inflation requires an instrument for distinguishing inflation according to its cause for policymakers. It is necessary to have the criteria according to which it is possible to determine the share of both groups in overall inflation. The author tests whether the contemporary versions of the cost-related vs. demand-related inflation dichotomy consider changes in total inflation as a sum of changes in individual prices and are able to cover the factors causing them. According to the author, in the microeconomic perspective, demand affects costs, and thus the growth in costs may be in part due to the growth in demand, which is a fundamental obstacle for distinguishing cost and demand-related reasons for growing prices. To conclude the macroeconomic view, the author mentions that the concept of cost vs. 
demand-related inflation dichotomy as a classification criterion must be abandoned due to doubts of its capacity to correctly distinguish both inflation types.

Poole (1960) maintains that the inflation analysis using the supply and demand curve cannot localise initial shocks. Distinguishing cost and demand-related inflation will not help, either. In individual sectors, it is necessary to assess cases in which the growth in demand expressed non-elastic supply or when growing costs may not be explained by the previous growth in demand. When examining net demand and cost-related inflation, it is also necessary to take into account unusual circumstances (investment or consumption boom, economy's openness, and increase in import prices). Due to the fact that there are a number of cost and demand shifts, it is also necessary to take into account the changes in other variables, which reduces the suitability of measurement of increasing prices using the shifts in the supply and demand curve.

Humphrey (1970) showed that the existing studies of partial balance of effective protection were not completely free of demand effects due to protection structures. The author applied the matrix method based on the input and output, which calculated the protection effectiveness rate in Argentina using Corden's correction. On the basis of the empirical study of R. Barth and J. T. Bennett (1975), the Simson's causality test points out one-way causality from money to wholesale and consumer prices. It also referred to an indirect causality from consumer prices to wages. These conclusions then confirm that inflation after the World War II was caused by growing money stocks, thus mainly having the demand-related character. According to the author, long-term changes in the volume of money determine temporary changes in prices. The primary source of accompanying inflation includes significant monetary expansion in the short-term. Therefore, there is doubt on the effectiveness of controlling wages and prices for the purposes of reducing inflation, as it shifts pressures elsewhere and suppresses their manifestation.

In the introduction, the analysis will outline inflation types and their causes according to selected authors. The first part will examine several ways of evaluating and quantifying the possible effect of household incomes including using the indicators of household disposable income and gross savings on inflation as published by the Czech National Bank. The second part will outline the data used, including the sources, and the decision will be made on the time interval. The third part will examine the development of the calculated indicators of potential demand-related inflation impulses originating in the household sector using historical data, incl. the comparison with the development of the household consumption deflator. The fourth part will explain the development of the overall relative household status using the development of the partial relative household statuses for individual income items. The fifth part will provide an analysis of the results of accumulated values of the overall demand-related inflation potential originating in households in the perspective of the stages of the economic cycle in the development of the real economy using the GDP indicator in fixed prices, incl. the verification using the development of the household consumption deflator. The sixth part will explain the development of the accumulated values of the overall demand-related inflation potential in individual stages of the economic cycle by means of calculating partial relative income statuses for household income items. The seventh part will outline the causes of the development of the household income status and the demand-related inflation potential at the time of the financial and economic crisis in the Czech economy in the 1990s and in both periods of the global financial and economic recession at the beginning of the 21st century and in the immediately following boom period. The eighth part with summarise all the conclusions. 


\section{Manners of evaluating and quantifying demand-related inflation impulses originating in the household sector}

According to the Czech National Bank (January 2001b), analyses of the demand-related inflation impulse are bases on wage examination as one of the components of household disposable income, which is a key factor of consumer and overall demand. The starting point for assessing the impact of household current income on inflation is the evaluation whether the dynamics of consumer demand (household consumption) encourages sellers to increase prices without regard to their cost or profit situation. Given the development of current income, it is necessary to consider a number of factors that may modify the households' consumption tendency. For instance, this may mean the households' tendency to make savings and the approach to debt financing, which is another source of consumption demand. In addition, it is necessary to consider the level of elasticity of the economy's supply side on the household income development, as one may not exclude increasing demand for import, which would reduce the pressures on the price growth. In connection with the estimate of the future inflation development, it is also necessary to analyse the elasticity of household expense items on the price growth, consumer sentiment and expectations of the economic development and own income. Substantial attention must also be paid to the factors modifying the impact of demand change on inflation. In particular, the may mean, for instance, the sales and price policy of retail chain stores.

The Inflation Reports (Czech National Bank, October 1998 to October 2001) show that it is the indicator of the relative household income status or simply the income status that serves as a basic tool for assessing the potential demand-related inflation pressures in the economy at the turn of the millennium. This indicator results from the comparison of the annual change of nominal current income and the GDP in current prices. The Czech National Bank labels the difference as the discrepancy between the development of the nominal GDP and current household income, expressed as a corresponding percentage. In the case that, for instance, current income grew at a slower rate than the GDP, then in comparison with the identical period of the previous year, there was no redistribution of the overall income in favour of households, which would excessively increase the amount of financial means in the hands of households. This lead to worsening the relative household income status, as there was a lower volume of financial means in the possession of households per GDP unit than in the same period in the previous year. As a result, there are no demand-related inflation pressures originating from the household sector and they may be considered insignificant. In the situation when, on the contrary, there was a more dynamic growth in current income than in the GDP, one may assume strengthening the relative household income status, which implies the presence of the demand-related impulse in the economy, potential risks of demand-related inflation pressures, and the risk of the overall imbalance in economy.

The situation reports on the economic and monetary development published on the website of the Czech National Bank with a delay (Czech National Bank, February 1999 to April 2000b) further clarify the evaluation of the presence and quantification of potential demand-related inflation pressures in the economy originating from the household sector by means of incorporating the disposable income indicator and gross savings indicator in the calculation. This indicator of the relative income status from the disposable income following the gross saving adjustment is a monetary expression of the imbalanced household purchasing power in billions CZK. The share of the resulting relative income status in the disposable income following the gross savings adjustment equals to the level of redistributing disposable income (following the gross savings adjustment) expressed as a percentage.

In this context, the Czech National Bank specifically enumerates, for instance, the total value of the corresponding redistribution in current prices owing to a slower growth rate of the 
nominal GDP compared to the growth rate of current income in billions CZK. This value is then compared to the disposable income adjusted with gross savings. This results in the redistribution rate of the disposable income (adjusted with gross savings) and generating a demand-related inflation impulse (\%), which is due to the development of household income not covered with the increase of the domestic supply. According to the Czech National Bank, this potential of the uncovered purchasing power may dissolve in additional imports or though increasing the domestic level of consumer prices. The manner of dissolving the accumulated demand-related inflation potential in the economy from the previous periods then depends on a number of internal and external effects (e.g. on the development of other relevant cost items and actual exchange relations). On the contrary, alleviating demand-related inflation pressures compared to the previous year may take place owing to a reduction in the redistribution of disposable income (after deduction of gross savings) in favour of households.

While for the purposes of outlining the discrepancies between the nominal GDP development and household current income, the Czech National Bank uses a graphical representation of the annual changes of both time series, the indicator of the relative income status in monetary terms is calculated using an algorithm which also takes into consideration the development of disposable income adjusted with gross savings. The first step calculates the value of noninflation current income of household in billions CZK (the actually published value of household current income in billions CZK at time $T^{*}$ annual change of the GDP value (\%) at time T / annual change of the value of household current income (\%) at time T). The second step compares the value of the actual household current income (in billion CZK) and enumerates the difference between them (in billions CZK). In the third step, it is necessary to multiply this difference with the share of the disposable income in household current income. In the fourth step, the resulting share of disposable income in the difference between the actual and non-inflation current income of households (the result of the third step) in billions CZK is multiplied by the share of disposable income adjusted with gross savings in disposable income. This resulted in the indicator of the relative income status from the gross disposable income (after being adjusted with gross savings), which assesses the potential demandrelated inflation pressures in the economy in monetary terms (in billions CZK). Another way of evaluation potential demand-related inflation pressures arising from the household sector includes the indicator of the share of the relative income status in the gross disposable income adjusted with gross savings. The level of redistributing disposable income adjusted with gross savings is expressed as a percentage. The indicator is calculated upon dividing the relative household income status by the household disposable income adjusted with gross savings.

Since January 2007, the Czech National Bank (Czech National Bank, May 2008) has extended analytical tools with a dynamic structural model ("g3"), which depicts the Czech economy in the form of levels and dynamics of quantities such as prices, wages and GDP components in the nominal and actual values, foreign trade and the exchange rate. Structural links in the model provide a detailed view of the relationship of nominal and real quantities or of the supply side of the economy in an analytically consistent framework. The basic difference compared with the previous structural model QPM (Quarterly Prediction Model), which the Czech National Bank used from 2002 to mid-2008, consists in a stronger embeddedness by microeconomic prerequisites. The economy in the g3 model includes the sector of businesses, households, state and foreign countries. The monetary policy is based on an inflation-targeting regime. The model is used to interpret the current development of the economy, to forecast future developments and for the risk analysis of the forecast. 


\section{Selection of the analytical tool, data, data sources, and time interval for the calculation of the indicators to outline demand-related inflation impulses arising from the household sector}

The data source will include the statistics of the national accounts of the Czech Statistical Office (CSO). In particular, this means the data of the annual GDP changes in current prices, or in fixed prices and the household consumption deflator. In addition, the analysis will also use the annual data of compensation of employees, gross operating surplus including gross mixed income, property income (received), social benefits other than social transfers in kind, and other current transfers (received) in current prices in billions CZK. For the purposes of the analysis, the items were added up and used further under the heading of current income. The current income item is referred to by the Czech National Bank, for instance, in the Table Annex of the Inflation Report (Czech National Bank, January 2001a, April 2001, and October 2001). It is also regularly referred to by the Ministry of Finance (Ministry of Finance, January 2015) in the document entitled the Macroeconomic Forecast of the Czech Republic. In the case of current income and individual household income items, annual changes (\%) were also calculated. The household sector was also used for the data of the gross disposable income and gross savings in current prices in billions CZK. Except for the GDP, the time interval for all the data was determined as the period of 1994 to, while the GDP in fixed prices has been available since 1996.

Due to a high degree of the sophistication of the apparatus of the structured QPM and g3 models, the application section will use the data to calculate the indicator of the total relative household income status as a means of evaluation and quantification of potential demandrelated inflation pressures arising from the household sector, defined in the first chapter of this analysis. The indicator of the total relative household income status according to the methodology of the Czech National Bank will be applied to the data in the form of the following two indicators:

- The relative income status using the gross disposable income adjusted with gross savings in billions CZK;

- The share of the relative income status in the gross disposable income adjusted with gross savings (\%).

The quantification of the total creation of demand-related inflation potential arising from the household sector according to the adopted indicators will be compared with the household consumption deflator, which will determine its justifiability and actual extent. Comparing the detected creation of the demand-related inflation potential according to the original indicator with the household consumption deflator will provide us with our own actual relative income status of households. It will help us distinguish cases when the occurring demand-related inflation impulses were absorbed in the current period prices from those when they exceeded such prices, thus actually leading to the creation of the demand-related inflation potential.

In addition, explaining the development of the total relative household income status and the origin of demand-related inflation potential will also make use of the methodology of the Czech National Bank, used for calculating our own partial relative income statuses for individual items of household income. In particular, this will include the item of wages and salaries and the gross operating surplus including the gross mixed income. In addition, it will include other income, consisting of the sum of property income, social benefits other than social transfers in kind and other current transfers. The indicator of partial relative income statuses will be applied on the data of individual types of household income in the form of the indicator of the relative income status taken from the gross disposable income adjusted with gross savings in billions CZK. 


\section{Analysis of the development of the indicators of demand-related inflation impulses originating from the household sector in the Czech economic environment using two indicators}

This chapter will analyse the development of the total relative income status in terms of two previously defined (Chapter 1) and data-supported indicators (Chapter 2), which will provide us with a comprehensive view of the potential demand-related inflation pressure originating from the household sector in the Czech economic environment.

The indicator of the relative income status from gross disposable income and adjusted with gross savings shows that in 12 years, there was a higher volume of funds in the possession of households per unit of the nominal GDP. The average value of the corresponding redistribution, given by a slower growth rate of the nominal GDP compared to the growth rate of the gross disposable income adjusted with gross savings, reaches 16.5 billion CZK in these years. In particular, the biggest impulse for creating demand-related inflation potential was found in 1994 (+26.1 bn. CZK), 1997 (+32.8 bn. CZK) and mainly in 2009 (+50.1 bn. CZK).

The indicator also implied the redistribution of the product to the detriment of households owing to a faster growth rate of the nominal GDP compared to the growth rate of the gross disposable income adjusted with gross savings. In the period of 9 years, the average value reached $23.5 \mathrm{bn}$. CZK. The most negative relative income status for the household was found in 1998 (-32.8 bn. CZK), 2004 (-42.1 bn. CZK), 2013 (-24.4 bn. CZK), and mainly in 2014 (42.8 bn. CZK).

\section{Figure 1}

Source: Own calculation on the basis of data from the Czech Statistical Office.

According to the indicator of the share of the relative income status in the gross disposable income adjusted with gross savings, the average value of the corresponding redistribution in current prices reached, in the previously localised 12 years, $1.5 \%$ of the gross disposable income adjusted with gross savings. As this represents only a negligible part of the household's gross disposable income, the resulting demand-related inflation potential may be labelled as relatively insignificant. Comparing this result with the household consumption deflator produced only two periods (2003 and 2009) which saw the creation of demand-related inflation potential (in the amount of $0.4 \%$ and $1.8 \%$ ). According to the indicator of the actual relative income status, in the remaining periods, the established impulses were absorbed in price development. In the case of the period with the highest redistribution of the product in favour of households, generating demand-related inflation impulses in the economy, caused by the development of the household's gross disposable income (adjusted with gross savings), may be perceived as more significant. In particular, in 1994, the share of the household relative income status in the gross disposable income amounted to $3.9 \%$, in 1997, it was $3.3 \%$, and in 2009 , it was $2.7 \%$. The development of the household's actual income status showed that except 2009, all these demand-related inflation impulses were dissolved in the current price level, thus not representing any threat for the following period.

Comparing the values calculated in the previous part and related to the redistribution of the product to the detriment of households with the value of the gross disposable income adjusted with gross savings revealed that its average value in the period of 9 years amounted to merely $1.5 \%$. This represents a negligible part of the gross disposable income of households. As this does not lead to any excessive increase in the volume of funds in the hands of households, there are no or only insignificant demand-related inflation pressures. Nevertheless, comparing the result with the development of the household consumption deflator increased the level of redistribution to the detriment of households up to amount of $4.1 \%$. According to the indicator 
expressed in nominal values, the periods with a higher intensity of product redistribution to the detriment of households included 1998 (3.1\%) and 2004 (2.9\%). The indicator of the actual income status of household increased the values in the corresponding years up to $10.8 \%$ and $5.8 \%$. In 2013 and 2014, the values of redistribution to the detriment of households declined again to $1.2 \%$ and $2.1 \%$ (expressed in actual values to $2.3 \%$ and $2.4 \%$ ).

\section{Explaining the development of the total relative income status using the calculation of partial indicators of the income status}

The view of the development of the total relative income status of household and the potential demand-related inflation pressures originating from the household sector, as defined by both indicators, will now be examined through the calculation of our own partial version of the indicator of the relative income status for individual income items of households (expressed only in nominal values).

Figure 2

Period

Source: Own calculation on the basis of data from the Czech Statistical Office.

The indicator of the share of individual sources of household income in the total relative income status, taken from the gross disposable income adjusted with gross savings, in billions $\mathrm{CZK}$, indicates that within the average value of redistribution in favour of households, and thus the higher volume of funds in the possession of households per unit of the nominal GDP in 1994 - 1997 (22.3 bn. CZK), the largest contributor (12.3 bn. CZK) included other income (sum of property income, social benefits other than social transfers in kind, and other current transfers), followed by wages and salaries of employees (+5.3 bn. CZK). The same situation was also found in 2010 ( +11.2 bn. CZK vs. +7.6 bn. CZK). On the contrary, in 2012, the value of redistribution in favour of households occurred as a result of wages and salaries and other income (+14.1 vs. +9.3 bn. CZK), whereas the gross operating surplus and gross mixed income reduced its value (by $11.7 \%$ ). In 2003 , improving the relative income status was due to only wages and salaries (by $8.6 \mathrm{bn}$. CZK), whereas the gross operating surplus, including the gross mixed income, and other income took the opposite effect (-2.3 and $-1.1 \mathrm{bn}$. CZK).

According to the calculation of relative income status, the reasons for the product redistribution to the detriment of households in 1998 included wages and salaries (-19.5 bn. CZK) and other income (- 9.3 bn. CZK). In 2007, this included mainly the gross operating surplus, including the gross mixed income $(-14.1 \mathrm{bn}$. CZK) and in 2014, it was the item of other income (-19.4 bn. CZK). In 2001 and 2011, wages and salaries prevented a more significant deterioration of the relative income status of household by supporting the redistribution of income in favour of households $(+1.6$ and +6.5 bn. CZK).

\section{The development of the accumulated values of the demand-related inflation potential according to the economic cycle stages}

This chapter will quantify the extent of product redistribution in favour of or to the detriment of the household sector using the indicators of the total relative income status of households in the perspective of the economic cycle stages (both in the nominal and actual versions), which will be derived, in this analysis, from the development in changes of the annual GDP dynamics in fixed prices. In this context, it is possible to localise 7 periods in the GDP development (in fixed prices), and accordingly, in the development of the indicators of the relative income status and potential demand-related inflation pressures. 
The recession in the GDP development (in fixed prices) was found in 3 periods. First, it was the period of 1997 and 1998, when the Czech economy was hit by the financial and economic crisis, and the economy declined annually by $0.7 \%$ and $0.3 \%$. Additionally, this economic cycle stage was localised in 2009. Here, the economy hit the first bottom of the global financial and economic recession with the annual GDP decline of $4.8 \%$ (in fixed prices). In the first case in 1998, compared to 1996, there was a stronger acceleration of the growth dynamics of the gross disposable income adjusted with gross savings than the GDP in current prices, which resulted in strengthening the household income status and indicated the creation of the demand-related inflation potential in the economy. The value of the corresponding redistribution amounted to $3.8 \mathrm{bn}$. CZK at the end of 1998 . However, a substantially stronger demand-related inflation impulse was found in 2009 (+50.1 bn. CZK). At the end of 1998, the accumulated value of redistribution amounted to $0.4 \%$ of the gross disposable income adjusted with gross savings. It thus represents a merely negligible part of the household's gross disposable income and any potential demand-related inflation pressures may be labelled as insignificant. In the case of 2009 , generating potential demand-related inflation impulses is more significant $(+2.7 \%)$. The comparison with the household consumption deflator revealed that in 1998, the accumulated demand-related inflation impulse was completed absorbed in the then price development. In 2009, there was a demand-related inflation potential of $1.8 \%$, which threatened to be released in the following years.

For the time being, the last recession hit the economy in the form of its second bottom in the period of 2012 and 2013, when the GDP (in fixed prices) declined annually by $0.8 \%$ and $0.7 \%$. The GDP development in current prices and the gross disposable income adjusted with gross savings show that at the end of 2013, compared to 2011, this income had grown less than the nominal GDP. The value of the product redistribution to the detriment of households amounted to $10.6 \mathrm{bn}$. CZK. Its comparison with the value of the gross disposable income adjusted with gross savings revealed that it amounted to $0.5 \%$. It is thus an insignificant part of the gross disposable income of households, not producing any demand-related inflation potential. Even after reflecting the development of the household consumption deflator, the level of redistribution to the detriment of household deepened further (to $4.1 \%$ ).

Figure 3

$$
\text { Period }
$$

Source: Own calculation on the basis of data from the Czech Statistical Office.

On the contrary, according to the GDP development in fixed prices, the presence of the boom in the economy was confirmed in 4 periods. The first one included the years 1994 to 1996. While in 1994 to 1995, we only have the GDP development in current prices, in 1996, this indicator (yet in fixed prices) grew annually by $4.3 \%$. In this period, the growth of the gross disposable income adjusted with gross savings exceeded the GDP growth (in current prices), thus strengthening the income status of households. The value of redistribution in favour of households amounted to 67.0 bn. CZK in 1996, which represented $7.6 \%$ of the gross disposable income adjusted with gross savings. The potential demand-related inflation pressures of this kind should already be considered significant. Nevertheless, according to the indicator of the actual income status, all the demand-related inflation impulses were absorbed within inflation of the then period.

The second period of this economic cycle stage lasted 10 years (from 1999 to 2008). It peaked in 2006 (the average GDP growth in fixed prices amounted to 4.1\%). In 2010 and 2011, it was a short transitional period between the first and second bottom of the global financial and economic recession with the GDP growth (in fixed prices) of $2.3 \%$ and $2.0 \%$. The economy returned to the boom in 2014. Compared to the same period of the previous year, the GDP (in fixed prices) grew by $2.0 \%$. The GDP development (in current prices) and the 
gross disposable income adjusted with gross savings show that in all these periods, the household income grew annually less than the nominal GDP. Compared to 1998, owing to the faster growth rate of the nominal GDP compared to the growth rate of the gross disposable income adjusted with gross savings, the value of the product redistribution to the detriment of households grew by $75.6 \mathrm{bn}$. CZK, by $5.8 \mathrm{bn}$. CZK compared to 2009, and amounting to 42.1 bn. CZK in 2014. The comparison of the value of product redistribution to the detriment of households with the value of the gross disposable income adjusted with gross savings revealed that the difference amounted to $4.1 \%$ or $0.3 \%$ and $2.1 \%$. Except the first period, it thus amounted to a small part of the household's disposable income. However, as there is no excessive increase in the volume of funds in the possession of households, there are no demand-related inflation pressures originating in the household sector. The comparison with the household consumption deflator further deepens the disadvantage of the household sector.

In the case that we analyse the development of the relative income status in the period of 2009 to 2014 jointly and the period of alternating recessions and anaemic growth, compared to 2008, we will find out that the conclusion on the product redistribution to the detriment of household is not so unambiguous, using the analysis of the economic cycle stages in individual years. At the end of 2014, the GDP in current prices rose, compared to 2008, more than the gross disposable income adjusted with gross savings. After reflecting gross savings, the value of the redistribution totalled at 4.2 bn. CZK, while in 2014 alone, it was $42.1 \mathrm{bn}$. CZK. In the whole period, the comparison of the product redistribution to the detriment of households with the value the gross disposable income adjusted with gross savings revealed the difference of merely $0.2 \%$, i.e. a negligible part of household income, while in 2014 alone, it was $2.1 \%$. According to the income status expressed in actual values, the redistribution to the detriment of households in 2014 was lower than in the whole period ( $2.4 \%$ vs. $6.9 \%)$.

\section{Explanation of the development of the accumulated values of the total relative income status of households in the economic cycles stages using a corresponding version for household income items}

In this chapter, the accumulated extent of product redistribution in favour of or to the detriment of the household sector and the corresponding presence or absence of potential demandrelated inflation pressures will be further specified using the indicators of the relative income status of households calculated for the particular sources of household income in billions CZK (expressed only in nominal values).

In the first and second recession period (1997-1998, and 2009), the faster growth of the gross disposable income adjusted with gross savings than the GDP (in current prices), which strengthened the income status of households and indicated demand-related inflation pressures in the economy, was due to releasing the item of the gross operating surplus including the mixed income and other income from the GDP development. The crucial part of the total value of the product redistribution in favour of households was due to other income (+16.5 bn. CZK). In 2009, the accumulated the demand-related impulse amounted to $29.7 \mathrm{bn}$. CZK in the case of the gross operating surplus incl. the gross mixed income and $26.3 \mathrm{bn}$. CZK in the case of other income. In the first period, wages and salaries had an opposite effect. In the third recession period (2012 and 2013), household income grew less than the nominal GDP. The total value of the product redistribution to the detriment of households consisted of the gross operating surplus incl. the gross mixed income and other income (19.0 and $6.9 \mathrm{bn}$. CZK); wages and salaries did not follow the GDP development and there was an increase in their partial income status, accumulating demand-related inflation potential.

\section{Figure 4}


Period

Source: Own calculation on the basis of data from the Czech Statistical Office.

On the contrary, in the first boom period (1994-1996), the increase in the gross disposable income adjusted with gross savings exceeded the GDP growth (in current prices), thus strengthening the household's income status. The total value of redistribution in favour of households comprised all the three components of household income, yet the highest contribution included the item of other income $(+30.4 \mathrm{bn}$. CZK) and the item of the gross operating surplus incl. the gross mixed income ( $+22.2 \mathrm{bn}$. CZK). The deterioration of the total income status of households in the second to the fourth boom period (1999-2008, 2010-2011 and 2014) was due to the gross operating surplus incl. the gross mixed income (the average value of $-36.3 \mathrm{bn}$. CZK) and other income (the average value of $18.3 \mathrm{bn}$. CZK). Wage and salaries showed the same trend only in 2014, when the value of the redistribution to the detriment of households amounted to $3.8 \mathrm{bn}$. CZK. In the second and third boom phase, this item did not correspond to the GDP development, when its partial income status amounted to $9.6 \mathrm{bn}$. CZK, on average, thus accumulating the demand-related inflation potential in this item.

The analysis of the development of partial relative income status in the period of years alternating recessions with an anaemic growth (2009 to 2014) implies that the total value of the product redistribution to the detriment of households was contributed only by the items of the gross operating surplus incl. the gross mixed income and other income. While in this common period of alternating recessions and an anaemic growth, the redistribution to the detriment of household amounted to 25.6 and $9.3 \mathrm{bn}$. CZK, in 2014 alone, it was 17.0 and $22.4 \mathrm{bn}$. CZK. In the joint period of alternating recessions and an anaemic growth, the relative income status taken from wages and salaries indicated deviating this income item from the GDP development (in the amount of $23.0 \mathrm{bn}$. CZK) and the creation of demand-related inflation potential. Nevertheless, the analysis showed that in 2014 alone, this item had the effect jointly with other household income items contrary to inflation, when the redistribution to the detriment of household amounted to $3.89 \mathrm{bn}$. CZK.

\section{Comparing the development of the relative income status of households at the time of the Czech financial and economic crisis and the global financial and economic recession and in the immediately following boom periods}

This chapter will compare the conclusions on the development of the relative income status at the time of the financial and economic crisis in the Czech Republic in the 1990s with the conclusions on the development at the time of the global financial and economic recession at the beginning of the 21 st century, as well as the immediately following boom period (both the nominal and actual version of the indicator). Furthermore, the overall view of the demandrelated inflation potential originating from the household sector is complemented with the conclusions on the development of partial income statuses calculated for specific components of household income.

Figure 5

\section{- WS $2008=100 \%$}

Source: Own calculation on the basis of data from the Czech Statistical Office.

The period of the financial and economic crisis in the Czech Republic (1997-1998) and the first bottom of the global financial and economic recession (2009) share the strengthening of the income status of households and the presence of the demand-related inflation impulse originating from the household sector (in actual values, it was absorbed in the price development in 1998, contributing to demand-related inflation potential in 2009). In the first 
period, the value of the total GDP redistribution in favour of households amounted to $3.8 \mathrm{bn}$. CZK, which represented $0.4 \%$ of the gross disposable income adjusted with gross savings. In the second case, it was the amount of $50.1 \mathrm{bn}$. CZK (2.7\%). At the time of the financial and economic crisis in the Czech Republic, the item of other income deviated from the GDP development $(+16.5 \mathrm{bn}$. CZK), while in the case of the gross operating surplus incl. the gross mixed income, the redistributed amount in favour of households was very low. During the first bottom of the global recession, both of these items contributed to the demand-related inflation potential originating from the household sector, yet with a higher vigour. At the time of the local crisis in the Czech Republic, the item of wages and salaries reduced the total income status of households by $12.2 \mathrm{bn}$. CZK, while increasing it by $6.5 \mathrm{bn}$. CZK at the time of the global recession. During the second bottom of the global recession (2012-2013), household income grew less than the nominal GDP (after reflecting the development of the household consumption deflator, the redistribution level to the detriment of households deepened even further). The total value of the product redistribution to the detriment of households was due to the gross operating surplus incl. the gross mixed income and other income (19.0 and 6.9 bn. CZK); wages and salaries did follow the GDP development, thus enhancing their partial income status and having the effect towards demand-related inflation potential originating from the household sector.

As for the boom periods immediately following the local financial and economic crisis and both phases of the global recession, it may be stated that in either case, we established the total income redistribution to the detriment of households (while it always deteriorated after incorporating the household consumption deflator). The highest value was found at the time after the local crisis (75.6 bn. CZK), followed by the boom period after the second bottom of the global recession (42.1 bn. CZK), while the last was the period after the first bottom of the global recession (5.8 bn. CZK). In addition, there are almost identical reasons for a lower annual growth of the gross disposable income adjusted with gross savings than the GDP. In the case of the gross operating surplus incl. the gross mixed income, the value of the partial redistribution to the detriment of households amounted to $71.5,20.4$ and $17.0 \mathrm{bn}$. CZK. In all these boom periods, other income had the identical effect. In the period after the local crisis and the first bottom of the global recession, the item of wages and salaries departed from the GDP development and the economy accumulated the demand-related inflation potential originating in the household sector in the amount of 8.9 and $10.2 \mathrm{bn}$. CZK. After the second bottom of the global recession, wages and salaries also supported the income redistribution to the detriment of households (its value was $3.8 \mathrm{bn}$. CZK), thus not excessively increasing the volume of funds in the possession of households and producing demand-related inflation pressures originating in the household sector.

\section{Conclusions}

Two indicators have been applied for the purposes of evaluating demand-related inflation pressures originating from the household sector. The indicator of the relative income status taken from the gross disposable income adjusted with gross savings calculated the average value of the redistribution in favour of households in the amount of $16.5 \mathrm{bn}$. CZK in the course of 12 years, while the average value product redistribution to the detriment of households was on the level of $23.5 \mathrm{bn}$. CZK in the course of 9 years. According to the indicator of the share of the relative income status in the gross disposable income adjusted with gross savings, in the previously localised 12 years, the redistribution in favour of households amounted to merely $1.5 \%$ of the gross disposable income and the resulting demand-related inflation potential may thus be labelled as relatively insignificant. The comparison of this nominal version of the indicator with the household consumption deflator established only two periods (2003 and 
2009) which saw demand-related inflation potential. In the remaining periods, the discovered impulses were absorbed in the then price development. In the period of remaining 9 years, the average value of the product redistribution amounted to merely $1.5 \%$, thus no longer implying the creation of demand-related inflation potential. The comparison with the development of the household consumption deflator increased the redistribution to the detriment of household to the value of $4.1 \%$.

According to the indicator of the share of individual sources of household income in the total relative income status taken from the gross disposable income adjusted with gross savings, what contributed most to the average value of the redistribution in favour of households, i.e. the higher volume of funds in the possession of households, in 1994-1997 and 2010 was other income, followed by wages and salaries. In 2012, the decisive item included wages and salaries and other income, while the gross operating surplus incl. the gross mixed income reduced the product redistribution in favour of households. In 2003, the relative income status was improved only by wages and salaries, as the gross operating surplus incl. the gross mixed income and other income took an opposite effect. According to the calculation of the partial relative income status in 1998, the product redistribution to the detriment of households was due to wages and salaries and other income, as well. In 2007, it was the gross operating surplus incl. the gross mixed income and in 2014, it was the item of other income. Wages and salaries prevented any larger deterioration of the relative income status of households in 2001 and 2011.

In terms of the economic cycle stages, the development of the indicators of the relative income status and potential demand-related inflation pressures originating from the household sector was divided into 7 periods. In the course of the first recession period (1997-1998) and the second recession period (2009), there was a faster growth of the gross disposable income adjusted with gross savings than the GDP in current prices. The value of redistribution in favour of households represented only a negligible part of the gross disposable income adjusted with gross savings, and thus an insignificant to very moderate potential demandrelated inflation pressures. Following the comparison with the household consumption deflator, in 1998, the accumulated demand-related inflation impulse was completely absorbed in the then price development. In 2009, there was a demand-related inflation potential in the amount of $1.8 \%$, which threatened to be released in the following years. Expressed in nominal values, the development was due to diverting the item of the gross operating surplus incl. the gross mixed income and other income from the GDP development. In both periods, wages and salaries had the opposite effect. Compared to 2011, at the end of 2013 (third recession period), household income grew less than the nominal GDP. The accumulated value of the product redistribution to the detriment of households also represented an insignificant part of the gross disposable income of households. After reflecting the development of the household consumption deflator, the level of redistribution to the detriment of households deepened even further. It applies to the effect of the items of the gross operating surplus incl. the gross mixed income and other income; wages and salaries did not follow the GDP development and had the effect in favour of the demand-related inflation potential.

In the period of the first boom (1994-1996), the growth of the gross disposable income adjusted with gross savings exceeded the GDP growth in current prices. The value of redistribution already represented significant potential demand-related inflation pressures, contributed by all three items of household income, yet the highest contribution was associated with the item of other income and the gross operating surplus incl. the gross mixed income. According to the indicator of the actual income status, however, all the demandrelated inflation impulses were absorbed by the inflation of the current period. In the second to fourth boom period (1999-2008, 2010-2011 and 2014), household income grew annually less 
than the nominal GDP. The value of the product redistribution to the detriment of households confirmed that except the first period, it only represented a small part of the gross disposable income of households. The comparison with the household consumption deflation further deepens the disadvantage of the household sector in all these periods. The deterioration of the total income status of households was due to the gross operating surplus incl. the gross mixed income and other income. Wages and salaries followed the same trend only in 2014. In the second and third boom phase, their development did not correspond to the GDP development, thus accumulating demand-related inflation potential through this item.

In the case that we jointly analyse the development of the relative income status in the period of 2009 to 2014 (the period of alternating recessions and an anaemic growth), it is necessary to significantly relativize the conclusions on the product redistribution to the detriment of households in 2014. Whereas in 2014 alone, it was $2.1 \%$ of the gross disposable income adjusted with gross savings, in the whole period, it was merely $0.2 \%$. According to the income status expressed in actual values, the redistribution to the detriment of households in 2014 was lower than in the whole period $(2.4 \%$ vs. $6.9 \%)$. The total value of redistribution was contributed only by the item of the gross operating surplus incl. the gross mixed income and other income. The relative income status of wages and salaries indicated, in the whole period, the separation from the GDP development and the creation of demand-related inflation potential. In 2014 alone, however, this indicator has the same effect as the other items of household income against the creation of demand-related inflation potential originating from the household sector.

The comparison of the period of the financial and economic crisis in the Czech Republic (1997-1998) and the first bottom of the global financial and economic recession (2009) implies the common strengthening of the income status of households and the presence of the demand-related inflation impulse originating from the household sector (in 1998, expressed in actual values, it was absorbed in the price development and in 2009, it resulted in a partial production of demand-related inflation potential). The value of the total GDP redistribution in favour of households amounted to $0.4 \%$ (in the first period) and $2.7 \%$ (in the second period) of the gross disposable income adjusted with gross savings. Both in the period of the financial and economic crisis in the Czech Republic and at the time of the first bottom of the global recession, the items of other income and the gross operating surplus incl. the gross mixed income deviated from the GDP development. At the time of the local crisis in the Czech Republic, the item of wages and salaries reduced the total income status of households, while enhancing it at the time of the global recession. In the course of the second bottom of the global recession (2012-2013), household income grew less than the nominal GDP (after the comparison with the development of the household consumption deflator, the redistribution to the detriment of household deteriorated even further). The total value of the product redistribution to the detriment of households was due to the development of the gross operating surplus incl. the gross mixed income and other income. Wages and salaries deviated from the GDP development, thus instigating the creation of demand-related inflation potential.

In the case of boom periods immediately following the local financial and economic crisis and both phases of the global recession, the product was always redistributed to the detriment of households, which was even deteriorated after incorporating the household consumption deflator. This development was due to the development of the item of the gross operating surplus incl. the gross mixed income and other income. After the local crisis and the first bottom of the global recession, the item of wages and salaries, on the contrary, contributed to the accumulation of demand-related inflation potential. However, after the second bottom of 
the global recession, it also supported the product redistribution to the detriment of households.

\section{References/Bibliography}

Barth, R. and Bennett, J. T., 1975. Cost-push versus Demand-pull Inflation: Some Empirical Evidence: Comment. Journal of Money, Credit and Banking, Vol. 7, No. 3, pp. 391-397. https://doi.org/10.2307/1991632

Bowen, G.W., 1960. Cost Inflation" versus "Demand Inflation": A Useful Distinction? Southern Economic Journal, Vol. 26, No. 3 pp. 199-206. https://doi.org/10.2307/1054952

Cempírek, L., 2013. Cílování inflace ve státech EU. Pardubice: Univerzita Pardubice, Fakulta ekonomicko-správní, Ústav ekonomických věd. Diplomová práce.

Czech National Bank, April 2000b. 3. Trh práce. Praha: Materiál k projednání v bankovní radě České národní banky, 4 . Situační zpráva o hospodářském a měnovém vývoji.

Czech National Bank, March 2000. 3. Trh práce. Praha: Materiál k projednání v bankovní radě České národní banky, 3. Situační zpráva o hospodářském a měnovém vývoji.

Czech National Bank, February 2000. 3. Trh práce. Praha: Materiál k projednání v bankovní radě České národní banky, 2. Situační zpráva o hospodářském a měnovém vývoji.

Czech National Bank, January 2000b. 3. Trh práce. Praha: Materiál k projednání v bankovní radě České národní banky, 1. Situační zpráva o hospodářském a měnovém vývoji.

Czech National Bank, December 1999. 3. Trh práce. Praha: Materiál k projednání v bankovní radě České národní banky, 12. Situační zpráva o hospodářském a měnovém vývoji.

Czech National Bank, November 1999. 3. Trh práce. Praha: Materiál k projednání v bankovní radě České národní banky, 11. Situační zpráva o hospodářském a měnovém vývoji.

Czech National Bank, October 1999b. 3. Trh práce. Praha: Materiál k projednání v bankovní radě České národní banky, 10. Situační zpráva o hospodářském a měnovém vývoji.

Czech National Bank, September 1999. 3. Trh práce. Praha: Materiál k projednání v bankovní radě České národní banky, 9. Situační zpráva o hospodářském a měnovém vývoji.

Czech National Bank, August 1999. 3. Trh práce. Praha: Materiál k projednání v bankovní radě České národní banky, 8 . Situační zpráva o hospodářském a měnovém vývoji.

Czech National Bank, July 1999b. 3. Trh práce. Praha: Materiál k projednání v bankovní radě České národní banky, 7 . Situační zpráva o hospodářském a měnovém vývoji.

Czech National Bank, May 1999. 3. Trh práce. Praha: Materiál k projednání v bankovní radě České národní banky, 5 . Situační zpráva o hospodářském a měnovém vývoji.

Czech National Bank, April 1999b. 3. Trh práce, př́imy domácností. Praha: Materiál k projednání $v$ bankovní radě České národní banky, 4 . Situační zpráva o hospodářském a měnovém vývoji.

Czech National Bank, February 1999. 3. Trh práce. Praha: Materiál k projednání v bankovní radě České národní banky, 2. Situační zpráva o hospodářském a měnovém vývoji.

Czech National Bank, January 2001b. Metodický rámec hodnocení mzdového vývoje ve vztahu k inflaci. Praha: Zpráva o inflaci.

Czech National Bank, May 2008. III. Makroekonomická prognóza a její předpoklady. Praha: Zpráva o inflaci-II/2008. 
Czech National Bank, October 2001. III. 4 Trh práce. Praha: Zpráva o inflaci.

Czech National Bank, July 2001. III. 3 Trh práce. Praha: Zpráva o inflaci.

Czech National Bank, April 2001. III. 3 Trh práce. Praha: Zpráva o inflaci.

Czech National Bank, January 2001a. III. 3 Trh práce. Praha: Zpráva o inflaci.

Czech National Bank, October 2000. III. 3 Trh práce. Praha: Zpráva o inflaci.

Czech National Bank, July 2000. III. 3 Trh práce. Praha: Zpráva o inflaci.

Czech National Bank, April 2000a. III. 3 Trh práce. Praha: Zpráva o inflaci.

Czech National Bank, January 2000a. III. 3 Trh práce. Praha: Zpráva o inflaci.

Czech National Bank, October 1999a. III. 3 Trh práce. Praha: Zpráva o inflaci.

Czech National Bank, July 1999a. III. 3 Trh práce. Praha: Zpráva o inflaci.

Czech National Bank, April 1999a. III. 3 Trh práce. Praha: Zpráva o inflaci.

Czech National Bank, January 1999. III. 3 Trh práce, príijmy domácností. Praha: Zpráva o inflaci.

Czech National Bank, October 1998. III. 3 Trh práce, príijmy domácností. Praha: Zpráva o inflaci.

Humphrey, B. D., 1970. Demand Inflation and Effective Protection. Southern Economic Journal, Vol. 37, No. 2 pp. 144-150. https://doi.org/10.2307/1056123

Janků, J., 2008. Co je inflace a jak se měři. Olomouc: Univerzita Palackého v Olomouci, Prírodovědecká fakulta, Katedra matematické analýzy a aplikací matematiky, Bakalářská práce.

Ministry of Finance, January 2015. Tabulky a grafy C.3 Trh práce. Praha: Makroekonomická predikce České republiky. Odbor finanční politika, ISSN 1804-7971.

Pavelka, R., 2005. Inflace a zdanění. Boskovice: Národohospodářská vyšší odborná škola, vyšší zdravotnická škola, Střední odborná škola a Střední odborné učiliště Boskovice. Absolventská práce.

Pospíšil, R., 2010. Měnově politické otázky financování vědy a výzkumu. Olomouc: Moravská vysoká škola Olomouc, o. p. c. Olomouc. ISBN 978-80-87240-28-1.

Poole, E. K., 1960. The Logical Distinction between Cost and Demand Inflation. Southern Economic Journal, Vol. 27, No. 1 pp. 62-64. https://doi.org/10.2307/1055792

Šmídová, J., 2004/2005. Inflace. České Budějovice: Vyšší odborná škola České Budějovice, Bachelor of Business Studies.

Žák, M., 2006. Hospodářská politika. Praha: Edice učebních textů. Ekonomie. Vysoká škola ekonomie a managementu.

\section{WEB LINKS}

Czech Statistical Office, 2015. GDP, National Accounts - Quarterly national accounts - Gross domestic product - time series.

https://www.czso.cz/csu/czso/hdp_cr

Czech Statistical Office, 2015. GDP, National Accounts - Quarterly national accounts - time series Tab_S1Transactions in Products and Distributive Transactions by Sector Corrected items D.7 and D.76 on the sheet "S2".

https://www.czso.cz/csu/czso/hdp_ts 